\title{
PECULIARITIES OF PROFESSIONAL TRAINING STANDARDS DEVELOPMENT AND IMPLEMENTATION WITHIN COMPETENCY-BASED APPROACH: FOREIGN EXPERIENCE
}

\begin{abstract}
The article analyzes the development of competency-based professional training standards and their implementation into educational process in foreign countries. It determines that the main idea of competency-based approach is competency-and-active learning, which aims at complex acquirement of diverse skills and ways of practice activities via mastering respective competences. The article states that competency is the product of competence due to which a person successfully realizes themselves in different spheres of their professional engagement, gains social independence and becomes mobile and qualified. The article also dwells on the international experience of professional and training standards development, it analyses specific internal national, as well as external all-European and worldwide conceptions of professional and training standards development, conceptual foundations of competency-based approach in national higher education within the framework of global information society formation. It highlights specific aspects of standards development based on activity-oriented technologies and professional competence assessment. The article states that within the framework of competency-based teaching and training, quality-assuring actions have to ensure the correspondence of standards and learning outcomes. It informs that the labour market is represented by employers, trade unions and the government. The article explores the fact that in Russia, Ukraine and many other countries the employers and the trade unions do not collaborate to formulate their needs with regard to professional training standards, that is why the government and its administration bodies have to do the task of predicting labour market needs on their own.

Key words: standards, conception, self-improvement, professional engagement, professional standardization, competency-based approach, European standards, curriculum, syllabus.

\section{INTRODUCTION}

Innovative information technology and global processes pose new challenges before the countries of the world in their educational policy domain.

In the context of the growing role of knowledge and technologies in social life, education is more and more positioned as an efficient instrument of forming the personality, who is able to live under conditions of dynamic changes. At the same time, extensive social changes and education modernization pose new demands with regard to training quality and professionalism of the future specialists. In this context scientists pay great attention to establishing the essence of modern standards of professional training, their implementation into educational process within competency-based approach, which is being practiced on a large scale in foreign and national higher education training.
\end{abstract}




\section{THE AIM OF THE STUDY}

We set it our goal to find out and analyze basic paradigmatic ideas of competencybased approach in foreign countries with the aim of determining possible ways of extrapolating such experience to national system of higher education.

\section{THEORETICAL FRAMEWORK AND RESEARCH METHODS}

The issues of modern standards implementation into educational process within competency-based approach have been studied by national and foreign scientists (N. Avsheniuk, N. Bidyuk, N. Bibik, V. Kremen, V. Luhovyy, O. Ovcharuk, O. Pometun, I. Ziaziun). K. Anderk, G. Bergman, O. Oleynikova, J. Ramen, R. White, I. Zimnyaya and others have explored the issues of competency-based approach in foreign pedagogy. These issues are crucial in national educational development governing documents, namely, National Theory of Higher Education in Ukraine, on Education Development Programme in Ukraine (2006-2010), Presidential Decree as of July 4, 2005 No 1013 "On High-Priority Measures Concerning the Support of Functioning and Developing Education in Ukraine", "Higher Education Act of Ukraine".

Peculiarities of professional training standards development and implementation within competency-based approach in foreign experience have been defined due to such methods as analysis, synthesis, analogy, comparison, individualization and generalization.

\section{RESULTS}

At this point of education development almost all economically-developed countries are switching or have switched over to the implementation of the competency-based standards. The mentioned approach is also important for Ukraine and its implementation is crucial for the near future, because only such an approach, as the practice shows, enables to provide production with the staff necessary for competitive economy.

We explore professional standardization in developed countries of Europe within the context of its most important aspects such as specific administration and professional standard development organization, competency-based approach implementation while forming professional standard structure and contents, the connection between standards and qualifications (Дубасенюк, 2011).

It is common knowledge that every country has its own legislatively assigned standards of providing their citizens with educational services, for example, in "Higher Education Act of Ukraine" there is a section dedicated to the mentioned issue.

We explore three classifications of standards of educational services offered to the citizens to satisfy their human needs:

- state notion about standards;

- educational system as presented in international standard classification of education;

- European standards and recommendations concerning internal and external higher education quality assurance (Стандарти і рекомендації щодо забезпечення якості в Європейському просторі вищої освіти, 2015).

The recommendations in the final item are specially developed to give assistance and provide guideline for higher educational establishments while developing their own quality-assuring systems and agencies in charge of independent inspection. We consider their analysis to be conceptually significant as nowadays our national educational system is being reformed to create common European area and we need to see if our standards correspond to the ones proclaimed in Europe.

As European standards have been mentioned, they need to be analyzed. The document says that their aim is, in the first place, to stimulate the development of higher 
educational establishments actively involved in research and education. The creation of common views on higher educational services and assuring their quality within the European Higher Education Area are also educational. As the document states, the standards promote quality in every single educational establishment and stimulate its transparency and openness to financial backing, international public integrity and state accountability, development and implementation of innovations leading to qualitatively new transformations in the sphere of educational system development and in the minds of people who are eager to be educated.

In international discussions there are certain mismatches in interpreting the notion of standard in terms of its application. For instance, European Training Foundation glossary says that professional standards are typically used to define what is expected of people at their working places. The mismatch between two types of standards (professional and training) is becoming more and more blurred as the standards are developed to bring the learning and training outcomes in line with labour sphere demands. Any standard can be used as a qualifying standard (Шамрай, 2003).

Summarizing the experience of a number of European countries we define common approaches to the professional standards content, which include:

- professional profile of training or vocational profile: the list of actions to do and their succession (independently or following the manual) for successful work by profession or professional activity;

- examination demands state what operations should be mastered during or by the end of the training with the enumeration of the minimal skills necessary to be demonstrated at the examination (they also state how the examination should be held, i. e. the content of oral and written parts of the test);

- entrance demands: here we find what educational certificate should be presented to be accepted to study a certain course. (In Germany, for example, one does not have to present an educational certificate in order to have access to "dual system" of professional education and training. In general, anyone can start studying within the limits of this education system, though this is an exception. In most countries one has to show the fulfillment of certain educational demands);

- curriculum: it describes learning goals (more or less detailed), theoretical and practical syllabus as well as the structure and duration of different sections and the whole course in accordance with existing standard.

In many countries higher professional education reforms are introduced in accordance with fundamental political, economic and political changes which urge to seek for adequate conceptions and approaches to solving issues posed by new conditions. Within this context the development of modern professional training standards is considered the most topical task (Стандарти і рекомендації щодо забезпечення якості в Свропейському просторі вищої освіти, 2015).

Apart from defining content and structure, we also need respective methods of developing and implementing new standards. It is common knowledge that professional training standards have to be developed in accordance with labour market demands, not with proposal. "Labour market" is synonym to needs of different economic spheres and, in particular, employers' demands, because it has to do with particular jobs.

Labour market is represented, in the first place, by employers, trade unions and the government. If, as it happens in Russia, Ukraine and many other countries, the employers and the trade unions do not collaborate to formulate their needs with regard to professional 
training standards, the government and its education administration bodies will have to do the task of predicting labour market needs on their own. In such case the standards have to be developed to be accepted by employers.

Some Central and Eastern-European countries' practice concerning creating educational and training curricula shows, that they either develop curricula by efforts of state professional institutions or have special departments for curriculum development in Ministry of Education.

In Germany the part of the curriculum, which refers to practice training at enterprises, is created in Federal Institute of Professional Education and Training. The part, which refers to vocational schools, is defined by Ministers of Education Conference.

In Austria the Ministry of Economics or other competent ministries, including the Ministry of Education, are in charge of curriculum development. Denmark has another approach, where there is a specific structure consisting of commerce-and-industry commissions at national and sectoral levels, which fully defines standards (Policies and Standards of the Commission on Occupational Education Institutions, 1992).

One of the aspects of training, implementations and support of professional training standards is their assessment. Its aim lies in determining the quality of the fulfilled tasks set by employers and stakeholders. It is about collecting and utilizing information relevant to curriculum decision-making.

In the Netherlands, for instance, the level of graduates' employment is analyzed in such manner, in Poland - the correspondence of professional training to local needs, and in Russia - the level of unemployment.

Qualifying standard demands may be developed vertically from the bottom (by educational establishments and/or at enterprises) or from top to bottom (by the state and/or the union of several establishments). In many countries there is a mixed order of accepting demands, both from top to bottom and from bottom to top.

The state plays a leading role in professional education regulation, and employers and employees take a second-rate part in this process in most cases at the level of their practical realization.

We can distinguish three functions of standard demands in terms of quality assessment. The basic function is to connect professional training and branches of economy, where graduates are employed. The second function is to aid to correlation of diplomas/certificates within a country. The third function can be supporting the qualifying level acknowledged by other countries. There are quite different approaches to the scope of utilizing qualifying levels (standards) worldwide. The following variations are possible:

- compulsory standard format at national level (typical of France);

- compulsory standard format at regional level (in the countries with great territory and structurally diverse regions, such as Poland);

- compulsory standard format within the limits of a particular sector or sphere (typical of the Netherlands) (Euroskills, 2008; WorldSkills Helsinki, 2005).

Despite rather great and diverse experience, professional training standard development worldwide does not give a clear answer to a number of principal questions.

Among them there are:

- Is it enough to indicate only the aim and learning result (outcome) or also describe the educational process instructor-student, which is used to reach such result (input plus outcome)?

- Is it necessary to master a real occupation with its demands reflected as standards or get basic knowledge / skills? 
- Do the standards have to refer to single professional activities or encompass the whole set of working engagement which constitute the given occupation?

- Do we have to give instructional priority to different occupations or more restricted list of occupations/qualifications of wider application?

- Do we have to set different levels of professional training or everybody has to get the same certificate of the same educational level?

Until quite recently in most developed countries state educational standards were based on predictions which determined the qualifications of the staff for several following years, in the best case - for a decade. The content of professional training was defined in accordance with the predicted manufactural development. Nowadays the idea of so called qualification stock is getting more and more widespread and used in standard model, it lies in training qualified specialists with the level of training which now may seem excessive, but in next years it will enable to develop a high-tech enterprise (Луговий, 2011).

So, professional standards development and implementation in developed European countries showed that economy development dynamics, cultural specifics and historically developed traditions influence their content. At the same time a number of principal approaches to professional standardization are common for these countries, namely, professional standard is the product of collaboration among employers, experts, education representatives, trade unions and public associations; specially created governance structures (councils or committees), which have strictly defined authorization rights are in charge of developing professional standards; standards development and correction are controlled by existing state legislation; professional standards structure is competency-based with the orientation to outcomes in a particular occupation; the basic method of professional standards content development is the functional analysis of occupational and personal competences demanded by labour market and arranged by qualifying levels and modules (occupational standards unit); organizational factors enable professional standard constant renewal and assessment of new competences gained by workers both while training and working; professional standards basic function is labour and training approaching by means of establishing legislative demands in terms of skills and personal qualities.

The stated above enables us to state that in foreign practice professional standards development is conditioned, in the first place, by the necessity to establish demands for quality of work, improving productivity, training quality, hands-on training and increasing employees' qualifications.

\section{CONCLUSIONS}

As we see, in different countries labour market analysis and professional training standards development are done using different methods, though the method of functional analysis is at bottom. Methods and mechanisms of analysis of labour market needs in European countries, despite the difference in approaches to problem detection and labour market development trends as well as involving different state and private structures enable us to find out that their efforts are given to constant monitoring, timely detection of problems, predictions and analysis of occupations in demand at state, regional and field levels and adequate reflection of research results in higher educational curricula.

Perspective we consider further detailed study of the outlined problem.

\section{REFERENCES}

1. Southern Association of Colleges and School 1886 Southern Lane. (1992). Policies and Standards of the Commission on Occupational Education Institutions. Georgia : Decatur, $353 \mathrm{p}$. 
2. World Skills Europe. (2008). EuroSkills 2008. Retrieved 24.11.2015 from : http://www.euroskills.org/activities/past-euroskills-events/euroskills-2008. and the biennial World Skills Competitions

3. World Skills. (2005). WorldSkills Helsinki 2005. Retrieved 24.11.2015 from : https://www.worldskills.org/what/competitions/wsc2005/.

4. Дубасенюк, О. А. (2011). Професійна педагогічна освіта : компетентнісний nidxid [Professional Teacher Education : Competency-Based Approach]. Житомир : Видво ЖДУ ім. І. Франка, pp. 40-46 (in Ukrainian).

5. Луговий, В. І. (2011). Освіта, навчання, інформація, компетентність : канонізація понять (теоретико-методологічний дискурс) [Education, Training, Information, Competency: the Canonization of Concepts (Theoretical and Methodological Discourse)]. In: Драгоманов, М. П. (Ed.). Історико-педагогічні ситуаиії : Науковий часопис [Historical-Pedagogical Situations : Scientific Journal], No 5, pp. 11-16 (in Ukrainian).

6. Стандарти і рекомендачії щодо забезпечення якості в Свропейському просторі вищої освіти [Standards and recommendations on quality assurance in European Higher Education Area]. (2015). Retrieved 20.11.2015 from : http://www.enqa.eu/indirme/ esg/ESG\%20in\%20Ukrainian_by\%20the\%20British\%20Council.pdf.

7. Шамрай, Н. Щ. (2003). Прочесс европейськой интеграиии и его влияние на системы профессионального образования [The Process of European Integration and its Influence on Occupational Training System]. M. : ITO, 136 p. (in Russian). 